\title{
Economic prospects of the power-plant industry development in Russia
}

\author{
Evgeny Lisin \\ National Research University \\ Moscow Power Engineering Institute \\ Russian Federation \\ lisinym@mpei.ru \\ Galina Kurdiukova \\ National Research University \\ Moscow Power Engineering Institute \\ Russian Federation \\ kurdiukovagn@mpei.ru \\ Wadim Strielkowski \\ University of Cambridge \\ United Kingdom \\ w.strielkowski@jbs.cam.ac.uk
}

Abstract. Our paper analyzes economic prospects and development of power engineering enterprises in Russian Federation. We show that despite the growth in use of renewable energy sources, the increase of organic fuel consumption is observed, and this is one of the key factors of traditional manufacturing efficiency improvement related to energy conversion in the power-plant industry in Russia. Cost forecast for mastering the manufacture of advanced generation equipment by Russian enterprises can yield the price competitiveness of the given type of products. Our results demonstrate that the increase in the share of expenses for research and development by means of mobilization of resources from generation enterprises might result in the considerable technological potential for Russian power-plant industry. We conclude that Russian power industry can achieve a dominant position at the domestic and global markets of power generation technologies provided new resources are secured for its development.

Keywords: economic development, power industry, technology, competitiveness

JEL Classification: O13, P28 


\section{INTRODUCTION}

In economic literature, any given national economy is defined by a set of industries, each of which is under control of relevant authorities (typically represented by ministries or other institutions) (Delgado et al., 2016). Hence, it seems crucial to design strategies in different sectors of national economy from the perspective of future generations in order to realize sustainable development concept on the national basis.

Power industry is the key sector of national economy providing its sustainable growth (Białowąs, 2015; Streimikiene et al., 2016). National security of energy supply is determined by the level of efficiency and operational reliability in power industry. Priority rates of energy sector development are expected in comparison with other sectors of economy due to necessity for meeting constantly growing requirements of economy in electric power.

In spite of the recent shift towards generation and use of renewable energy sources (RES), the increase of organic fuel consumption remains the main pillar of energy generation in Russian Federation (as well in many other countries around the globe), and a factor that still remains one of the key ones for traditional manufacturing efficiency improvement related to energy conversion in power-plant industry in the country. In order to assess the economic potentials as well as to draw scenarios of future development for the powerplant industry in Russia, cost forecast methods seem to provide appropriate tools. Cost forecast methods can be used for mastering the manufacture of advanced generation equipment by Russian enterprises and for eliciting the price competitiveness of the given types of products or services they provide. It often happens that the increase in the share of expenses for research and development (R\&D) sector obtained from shifting the necessary resources from generation enterprises might result in considerable enhancement of technological potential of the power-plant industry.

The postulates and objectives articulated above constitute the main idea and the key value-added of this paper. The paper sets a goal to provide recommendations for Russian power industry in order to help it achieve a dominant position at the domestic and global power generation markets and to become truly competitive and self-sustainable.

This paper is structured as follows: Section 2 provides a comprehensive literature review. Section 3 elaborates on the state of the power-plant industry in Russia. Section 4 provides a methodology of the cost forecasting methods. Section 5 reports on the empirical model of cost forecasting and its main results. Finally, section 6 concludes the paper with some remarks and discussions.

\section{LITERATURE REVIEW}

Evaluation of world data on construction of all kinds of generating facilities allows for the conclusion about considerable energy consumption growth over the last 30 years (Figure 1). Despite the achieved capacity gain of alternative and renewable energy sources over the past decade, the increase of typical fuel and energy resources (oil, gas, coal) consumption is observed, and traditional thermal power industry based on chemical transformation of organic fuel still dominates (Urbaniec, 2015).

Thermal power plant (TPP) is a generating unit in traditional power industry. Active use of organic fuel at TPP plant in order to satisfy demand for electric power along with resource limitation is among the key factors of energy conversion technological development.

Global power-plant industry development is focused on amplification of initial steam parameters pressure $p_{0}$ and temperature $t_{0}$. From thermodynamic perspective it is the only possible way to improve considerably the efficiency of power plant turbo generator. Thus, $t_{o}$ increase by $1 \%$ results in upgrading TPP plant efficiency by an average of $0.13 \%$, and $p_{0}$ increase - by $0.0086 \%$ (Lisin et al., 2015a; Breeze, 2014). 
However, steam temperature increase is limited by physical properties of modern steel. At present time, the ultimate temperature level for steel is $600-620^{\circ} \mathrm{C}$ (Masuyama, 2001).

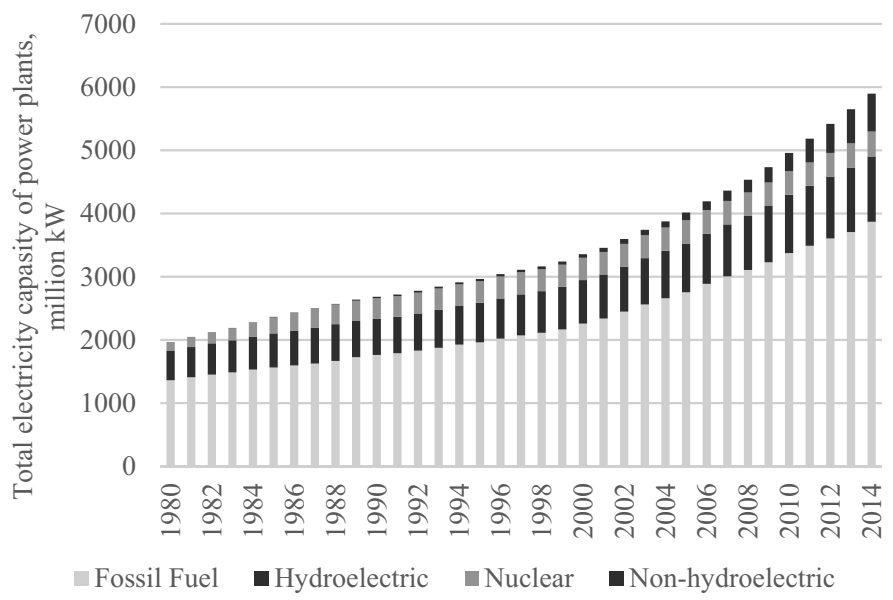

Figure 1. Plant capacity global change according to types of energy sources Source: U.S. own research based on (International Energy Statistics, 2016).

Steam initial temperature increase results in efficiency improvement of a generating unit, and escalation of capital costs as well. Escalation of capital costs is caused by necessity for extensive use of high-priced heat-resistant steel within metal costs of power-generating equipment (Breeze, 2014; Zhang, 2013). From the perspective of economic feasibility of high-efficient electric power generation technologies, unit power improvement shall be observed.

Table 1 lists the key technical and economic parameters of power generation technologies based on solid fuel with different efficiency levels.

Table 1

Technical and economic parameters of coal-fired generation technologies

\begin{tabular}{|l|c|c|c|}
\hline \multirow{2}{*}{ Technical parameter } & \multicolumn{3}{|c|}{ State of technology } \\
\cline { 2 - 4 } & $\begin{array}{c}\text { Supercritical parameters } \\
\text { (SC) }\end{array}$ & $\begin{array}{c}\text { Ultra-supercritical param- } \\
\text { eters (USC) }\end{array}$ & $\begin{array}{c}\text { Advanced ultra-supercritical } \\
\text { parameters (A-USC) }\end{array}$ \\
\hline Capacity level, MW & 300 & 660 & 1000 \\
\hline Efficiency level, \% & 40 & 45.3 & 50 \\
\hline $\begin{array}{l}\text { Superheated steam tempera- } \\
\text { ture, }{ }^{\circ} \mathrm{C}\end{array}$ & 540 & 600 & 720 \\
\hline $\begin{array}{l}\text { Superheated steam pressure, } \\
\text { MPa }\end{array}$ & 24 & 30 & 35 \\
\hline $\begin{array}{l}\text { Specific capital investments, } \\
\text { U.S. dollars/ } \mathrm{kW}\end{array}$ & 1680 & 1900 & 2240 \\
\hline
\end{tabular}

Source: own research based on (Sargent \& Lundy, 2009; Bechtel Power Corporation, 1981; Zhang, 2013). 
Development and assimilation of innovative high performance power generation technologies require considerable investments associated with competitiveness of power engineering enterprises in the country. Competition between Russian enterprises and foreign manufactures of power-generating equipment is peculiar to power-plant industry in Russia. Poor international credit rating of Russian enterprises diminishes a chance of favorable financial terms to be offered by commercial banks. In this regard, production prime cost of Russian power engineering enterprises is higher compared to foreign counterparts (Frolova, 2014). This fact predetermines dependence on foreign technologies in power-generating sector of the country.

\section{CURRENT STATUS OF POWER-PLANT INDUSTRY IN RUSSIA}

Russian power engineering enterprises produce the main and accessory equipment for TPP, nuclear, hydraulic and gas-turbine power plants.

Although Russian power engineering enterprises have come out of recession caused by structural changes of industry in the early 1990s (Hill, 1998), they hold weak positions in the domestic market after quarter of a century being engaged primarily in the export of energy products.

First of all, this is due to the fact that global companies built their business in Russia while the majority of industry enterprises were at a low ebb. Such global producers of power equipment as Siemens, Alstom, General Electric, almost completely hold the market of power-generating equipment, and supply their products for power plant construction and alteration. Under these conditions, the Russian power-plant industry is associated with auxiliary production (Mityushin et al., 2008; Mikhailov et al., 2012).

Lack of sufficient funds available for investment in modernization of manufacturing equipment and improvement of product quality, as well as breach of time-honoured relations with partners, are also among the key reasons of the current situation for Russian enterprises. Nevertheless, demand for power equipment from Russian generating companies remains sufficiently high, considering that about $43 \%$ of all generating capacities in Russia reached the end of their service life (Rezinskikh, 2010).

At the same time, an intense expansion of foreign power-plant enterprises is observed by uniting of global producers in consortiums. This is due to the fact that Russian producers appear to be non-competitive in view of high manufacturing costs and they are not ready to perform turnkey services (Salnikov, 2006).

Along with that, the Russian power-plant industry preserved substantial potential for sustainable innovative and technological development. Fluctuations in the load of Russian power engineering enterprises do not allow to accelerate modernization just at their own expenses. As a result, maximum share of costs for research and development is equal to $5 \%$ of cumulative investment. In the meantime, research and development are equally conducted by different foreign enterprises, and at times even with predominant co-funding from future product consumers - the largest generating companies (Mikhailov et al., 2012; Rodionov et al., 2014).

More than 50 enterprises are involved in power-plant industry of Russia. Industrial group JSC "Siloviye Mashiny" and JSC "Atomenergomash" hold the key positions. From the perspective of competitiveness on the foreign markets, only industrial group JSC "Siloviye Mashiny" provides complete cycle from development to production and maintenance of power-generating equipment at all electric power plants. Other companies focus on particular products (Danilin, 2010).

The following activities represented in Table 2 can be distinguished in the structure of Russian powerplant industry. 
Key producers of power-generating equipment

\begin{tabular}{|c|c|}
\hline Production activity & Producers \\
\hline Turbine equipment manufacturing & $\begin{array}{l}\text { "Leningrad Metal Plant” (JSC "Siloviye Mashiny"), "Turbine } \\
\text { Bucket Plant" (JSC “Siloviye Mashiny"), "Kaluga Turbine } \\
\text { Plant" (JSC "Siloviye Mashiny") }\end{array}$ \\
\hline Manufacturing of electrical machines and equipment & $\begin{array}{l}\text { "Electrosila" (JSC “Siloviye Mashiny"), JSC } \\
\text { "Uralelectrotyazhmash", JSC "Elsib" }\end{array}$ \\
\hline Boiler equipment manufacturing & $\begin{array}{l}\text { JSC "Podolsk Machine Engineering Plant”, LLC } \\
\text { "Belenergomash", JSC TKZ "Krasnyi kotelshchik" (JSC } \\
\text { "Siloviye Mashiny"), LLC “Sibenergomash" }\end{array}$ \\
\hline $\begin{array}{l}\text { Manufacturing of pipelines, fittings, pipes, and their } \\
\text { components for power industry and other industrial } \\
\text { fields }\end{array}$ & $\begin{array}{l}\text { JSC “Energomash (Chekhov)", LLC "Belenergomash”, LLC } \\
\text { "Sibenergomash", "Turbine Bucket Plant” (JSC "Siloviye } \\
\text { Mashiny"), "Nevsky Plant" (JSC “REP Holding”) }\end{array}$ \\
\hline $\begin{array}{l}\text { Manufacturing of unique pumping equipment, exhaust } \\
\text { and draft units }\end{array}$ & $\begin{array}{l}\text { "Leningrad Metal Plant", "Nevsky Plant", "Sibenergomash", } \\
\text { "Uralgidromash" }\end{array}$ \\
\hline Metallurgical production & $\begin{array}{l}\text { "Leningrad Metal Plant” (JSC “Siloviye Mashiny”), "Turbine } \\
\text { Bucket Plant" (JSC "Siloviye Mashiny"), JSC "Proletarskiy } \\
\text { Plant" }\end{array}$ \\
\hline Nuclear power equipment manufacturing & $\begin{array}{l}\text { JSC “AEM-technologies” (JSC “Atomenergomash”), JSC } \\
\text { "Podolsk Machine Engineering Plant” }\end{array}$ \\
\hline Integrated design of power sites & JSC "Siloviye Mashiny" \\
\hline
\end{tabular}

Source: own research based on (Cardu et al., 1994; Danilin, 2010; Mikhailov et al., 2012).

The largest producer in the global market of power plant engineering is General Electric, controlling $29 \%$ of the whole market, Siemens ranks second with $19 \%$, and the next is Alstom $-16 \%$. The market share of all Russian power engineering enterprises is no more than $2 \%$, and $1.5 \%$ is accounted for by JSC "Siloviye Mashiny" (Danilin, 2010).

Currently, the pursuance of research and development and application of their results in manufacturing are among the key problems of Russian power plant engineering enterprises. Research and development are expensive, and Russian energy companies are either not sufficiently interested, or they cannot conduct R \& $\mathrm{D}$ considering lack of positive experience in cost management during new power equipment manufacturing. In this regard, production of Russian enterprises is either technologically imperfect, or designed according to foreign technologies using imported parts. Poor development of scientific and engineering solutions in production chain cuts down renewal and growth opportunities.

Almost all production of Russian power engineering enterprises is sector-specific and characterized by small demand for output product. Year after year, intense foreign competition is observed, and innovation rate of Russian engineering business remains low.

At present time, modernization of equipment and assimilation of new manufacturing technologies may enhance competitiveness of the Russian power engineering enterprises and provide security of energy supply in the country. At achieving these purposes under current economic conditions, it is necessary to manage costs of new power equipment manufacturing. Cost forecast for new power equipment during research and development stage is of prime importance. This could allow for attracting investments in power engineering sector from generating companies at early stage of scientific product development, as well as promoting advanced development and upgrading experimental and computing bases of power engineering enterprises. 


\section{METHODOLOGY}

A principal issue of power-plant industry under current market conditions is reaching the desired efficiency level at power equipment manufacturing. To solve the given problem, an enterprise should quickly change production object modifying structural form and dimensions, product characteristics, materials and manufacturing technology. This allows to maintain steady demand for output product. During engineering study it is necessary to forecast launching costs.

At forecasting costs of new power equipment, the following factors must be considered (Rubin et al., 2007; Lisin et al., 2015b):

- High cost and turnaround time,

- High capital/output ratio,

- Long payback period of investment projects,

- Slow technological changes,

- Quite small production batch.

All private forecast objects are interconnected in power industry and set a unified complex of prediction of scientific and technical processes. The main predicted parameters in power-plant industry are: (Colpier et al., 2002; Lisin et al., 2015a)

- Launching costs;

- Technical parameters (pressure, temperature);

- Technical resources and life time;

- Design characteristics;

- Assimilation of new metals;

- Changes in power engineering technologies.

Currently, different methods of cost forecasting are used due to continuing theoretic development related to variable economic conditions and increasing the capabilities of researchers.

Conceptual design outputs allow for total cost assessment based on analogue method (Makridakis et al., 1998). At forecasting costs of new power equipment, analogue method can be used by selecting the prototype as a basic version that is structurally similar to a new processing unit and having similar technicaleconomic values (Kehlhofer et al., 2009). So we get the following formula:

$$
C_{e q}^{\text {new }}=C_{e q}^{\text {base }} \cdot \prod_{i=1}^{n} k_{i}
$$

where $k_{i}$-coefficients taking into account cost increase (reduction) due to change of design and parameters of a new equipment; $C_{e q}^{\text {base }}$ - cost of equipment taken as a basic version for calculation.

Analogue method is not perfect and has disadvantages. The case is that technological changes are less associated with past experience under dynamic market conditions and new developments. Thus, application of the given method provides less accurate results.

Correlation and regression analysis methods are also used during new equipment cost calculation. These statistical methods are intended to determine relationship between technical and economic parameters and production prime cost.

For instance, in order to estimate the manufacturing cost of new steam turbines the following parameters of a correlative model can be used:

- Nominal capacity;

- Initial pressure and steam temperature;

- Turbine net mass. 
Correlation and regression models of prime cost definition based on power equipment parameters can be used at early stage of new equipment design. However, these models have disadvantages when used in respect of machine engineering. The most serious among them are:

- Disregard of structural complexity and novelty;

- Removal of physical output indicators from analysis, affecting the prime cost by the way of fluctuating charges;

- Disregard of suitability, continuation and specialization of existing production at manufacturing power equipment of standard size.

Thus, correlation analysis method is of limited application even at early stage of design process.

During technical and economic forecasting, dependence of new equipment production efficiency on variable and fixed costs ratio is of great importance considering predominant single-unit production in power-plant industry.

Prime cost structure of new power equipment through the example of a new steam turbine production can be presented by formula:

$$
S_{\text {turbine }}=S_{\text {metal }}+S_{\mathrm{PP}}+S_{\text {salary }}+S_{\text {service }}+S_{\text {factory }}+S_{\text {depreciation }}+S_{\text {other }}
$$

where $S_{\text {metal }}$ - material consumption (first of all, high-melting-point alloys and metals), $S_{\mathrm{PP}}$ - launching costs, $S_{\text {salary }}$ - salary costs, $S_{\text {service }}$ - equipment service expenses, $S_{\text {factory }}$ - factory expenses, $S_{\text {depreciation }}$ - depreciation expense, $S_{\text {other }}$ - other expenses.

Table 3 gives the suggested cost-per-unit structure in power-plant industry.

Table 3

Suggested new production prime cost structure in power-plant industry

\begin{tabular}{|c|l|r|}
\hline$\#$ & \multicolumn{1}{|c|}{ Description of steam turbine manufacturing costs (without condenser) } & $\%$ \\
\hline 1 & Materials (high-melting-point alloys and metals) & 55.5 \\
\hline 2 & Launching costs & 1.7 \\
\hline 3 & Salary costs & 7.6 \\
\hline 4 & Equipment service expenses & 21.4 \\
\hline 5 & Factory expenses & 7.3 \\
\hline 6 & Depreciation expense & 4.4 \\
\hline 7 & Other production and non-production expenses & 2.1 \\
\hline
\end{tabular}

Source: own research based on (Lisin, E et al., 2015b; Kehlhofer et al., 2009).

Having combined last four components (2) into total fixed cost summary, we get the following formula:

$$
S_{\text {turbine }}=S_{\text {metal }}+S_{\mathrm{PP}}+S_{\text {salary }}+S_{\text {fixed }}
$$

Graphical description of the given functional dependence is shown in Figure 2. 


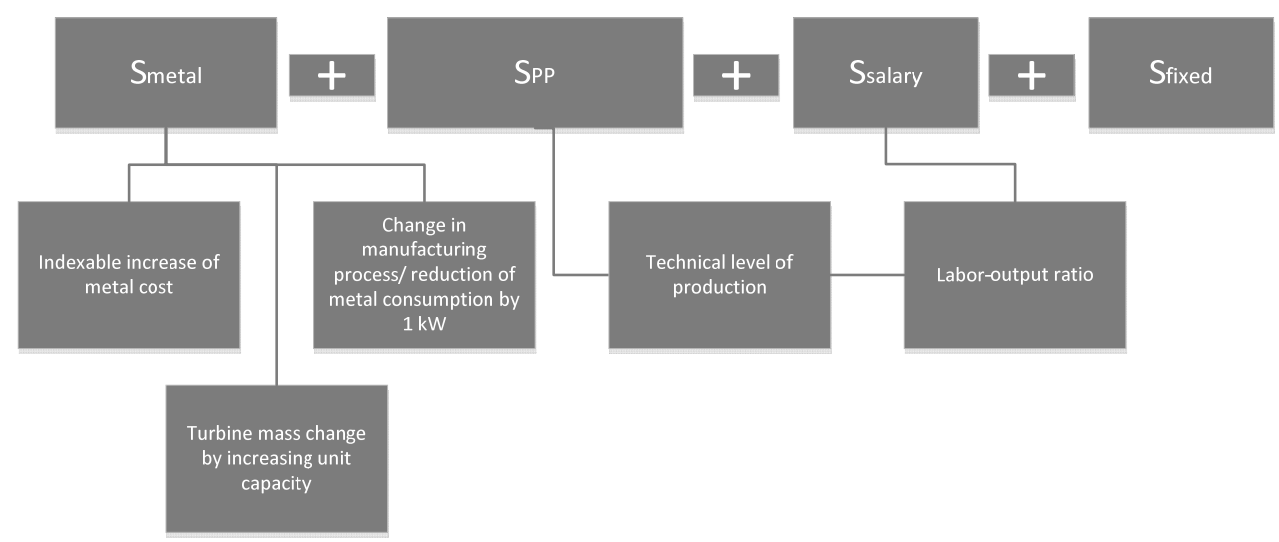

Figure 2. Prime cost structure of new power equipment and affecting factors Source: own development.

As it appears from the presented prime cost structure of new power equipment manufacturing, the majority of costs are expended on materials by power engineering enterprises.

\section{EMPIRICAL MODEL OF COST FORECASTING}

Technological development of generation equipment is oriented to installed unit capacity growth. This allows for efficiency improvement and operating costs reduction. From the perspective of production prime cost, on the one hand, change in manufacturing process results in reduction of metal consumption per unit capacity, on the other hand, turbo generator mass increases and it is necessary to use pricier heat-resistant steel. Assessment of the impact of the used metal amount on prime cost of a new power unit with its installed capacity growth will allow to make cost forecast for new power equipment.

Enormous amount of metal is consumed during production of turbine and boiler units. For instance, the mass of K-300-240 steam turbine with a capacity of $300 \mathrm{MW}$ is 700 tonnes, and the mass of K-800-240 steam turbine with a capacity of $800 \mathrm{MW}$ is 1300 tonnes. In this case, metal consumption during turbine production is almost twice the mass of manufactured power unit.

High-strength heat and pressure resistant metals are used in steam turbine manufacturing. Rise of steam parameters and installed unit capacity results in high-alloy steel consumption increase.

Providing high heat resistance of steel by using doping materials including molybdenum, wolframium, nickel, vanadium and cobalt is among the key factors constraining the use of extra-high, supercritical and ultra supercritical steam parameters. These materials are very expensive. Currently high-priced titanium is coming into use at steam turbines with supercritical parameters.

Metal utilization factor $\eta$ increase is of great importance for power-plant industry. Metal utilization factor is quite low in steam turbine manufacturing. Disparity between semi-finished and final product mass (net weight) is observed. $\eta=0.54-0.7$ during high capacity turbine production (Leyzerovich, 2008).

Consumption of different materials during power equipment manufacturing is shown in Figure 3. 


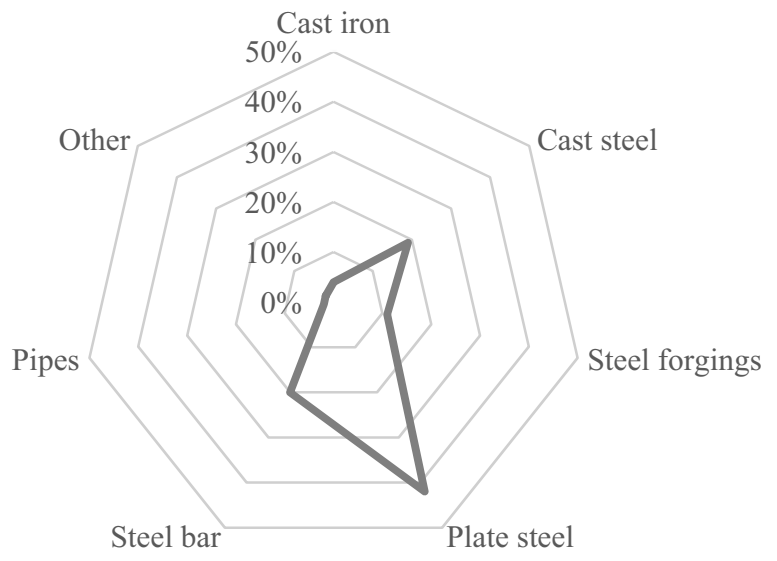

Figure 3. Material structure at power equipment production in steam turbine manufacturing Source: own development based on (Leyzerovich, 2008; Kehlhofer et al., 2009).

Considering the structure presented in Figure 3, we get calculation formula for weighted average cost of metal:

$$
\begin{aligned}
c_{\text {metal }}= & 0.04 \cdot c_{\text {cast iron }}+0.19 \cdot c_{\text {cast steel }}+0.11 \cdot c_{\text {steel forgings }}+0.42 \cdot c_{\text {plate steel }}+ \\
& +0.2 \cdot c_{\text {steel bar }}+0.02 \cdot c_{\text {pipes }}+0.02 \cdot c_{\text {other }}
\end{aligned}
$$

Information on net mass and consumption of steel at manufacturing a number of steam turbines is given in Table 4.

Table 4

Mass and consumption of steel at steam turbine manufacturing (without condenser)

\begin{tabular}{|l|c|c|c|c|}
\hline \multirow{2}{*}{ Standard sizes } & \multirow{2}{*}{ Net mass, tonnes } & \multicolumn{3}{|c|}{ Including steel consumption, tonnes } \\
\cline { 3 - 5 } & & High-alloy steel & Stainless steel & Austenitic high-alloy steel \\
\hline $\mathrm{K}-100-90$ & 283 & 116 & 89 & 0.2 \\
\hline $\mathrm{K}-150-130$ & 395 & 235 & 45 & 3.4 \\
\hline $\mathrm{K}-200-130$ & 581 & 162 & 50 & 1.4 \\
\hline $\mathrm{K}-300-240$ & 700 & 362 & 107 & 13 \\
\hline
\end{tabular}

Source: own development based on (Leyzerovich, 2008).

Steam turbine technical level parameters are shown in Table 5. 
Steam turbine technical level parameters

\begin{tabular}{|l|c|c|c|c|c|}
\hline \multicolumn{1}{|c|}{ Unit name } & K-200-130 & K-300-240 & K-500-166 & K-800-240 & K-1200-240 \\
\hline Nominal capacity, MW & 200 & 300 & 500 & 800 & 1200 \\
\hline $\begin{array}{l}\text { Turbine specific mass } \\
\text { (without condenser and aux- } \\
\text { iliary equipment), kg/kW }\end{array}$ & 2.66 & 2.3 & 1.89 & 1.625 & 1.58 \\
\hline
\end{tabular}

Source: own development based on (Leyzerovich, 2008).

Based on data presented in Table 5 we compose regression model reflecting turbine specific mass $m$ change depending on installed capacity $N$. This dependence is nonlinear and described by the following statistical evidence:

$$
\hat{m}=a_{1}+\frac{a_{2}}{N}+\frac{a_{3}}{N^{2}}
$$

where $a_{1}, a_{2}, a_{3}$ - regression coefficients.

Then we make change of variables $N^{\prime}=\frac{1}{N}$ and submit (5) in multinominal $\hat{m}=a_{1}+a_{2} \cdot N^{\prime}+a_{3} \cdot\left(N^{\prime}\right)^{2}$ . We use least square method to determine regression coefficients. We shall solve the following combined equations:

$$
\left\{\begin{array}{l}
a_{1} n+a_{2} \sum_{i=1}^{n} N_{i}^{\prime}+a_{3} \sum_{i=1}^{n} N_{i}^{\prime 2}=\sum_{i=1}^{n} m_{i} \\
a_{1} \sum_{i=1}^{n} N_{i}^{\prime}+a_{2} \sum_{i=1}^{n} N_{i}^{\prime 2}+a_{3} \sum_{i=1}^{n} N_{i}^{\prime 3}=\sum_{i=1}^{n} N_{i}^{\prime} m_{i} \\
a_{1} \sum_{i=1}^{n} N_{i}^{\prime 2}+a_{2} \sum_{i=1}^{n} N_{i}^{\prime 3}+a_{3} \sum_{i=1}^{n} N_{i}^{\prime 4}=\sum_{i=1}^{n} N_{i}^{\prime 2} m_{i}
\end{array}\right.
$$

where $n$ - number of experimental power units.

We receive the following model of assessment of specific mass depending on installed capacity:

$$
\hat{m}=3.249-\frac{0.615}{N}+\frac{0.055}{N^{2}}
$$

Then cost of materials required for a new steam turbine manufacturing shall be defined as follows:

$$
S_{\text {metal }}(N)=m(N) \cdot C_{\text {metal }}(N)
$$

Power unit technical level increase contributes to installed capacity growth. In such case, power unit specific mass per unit capacity reduces and metal specific cost per unit mass increases due to share growth of expensive heat-resistant steel.

Being aware of share of material costs at new product manufacturing (Figure 3) we obtain the cost forecast for new power equipment with its installed capacity growth (Figure 4). 


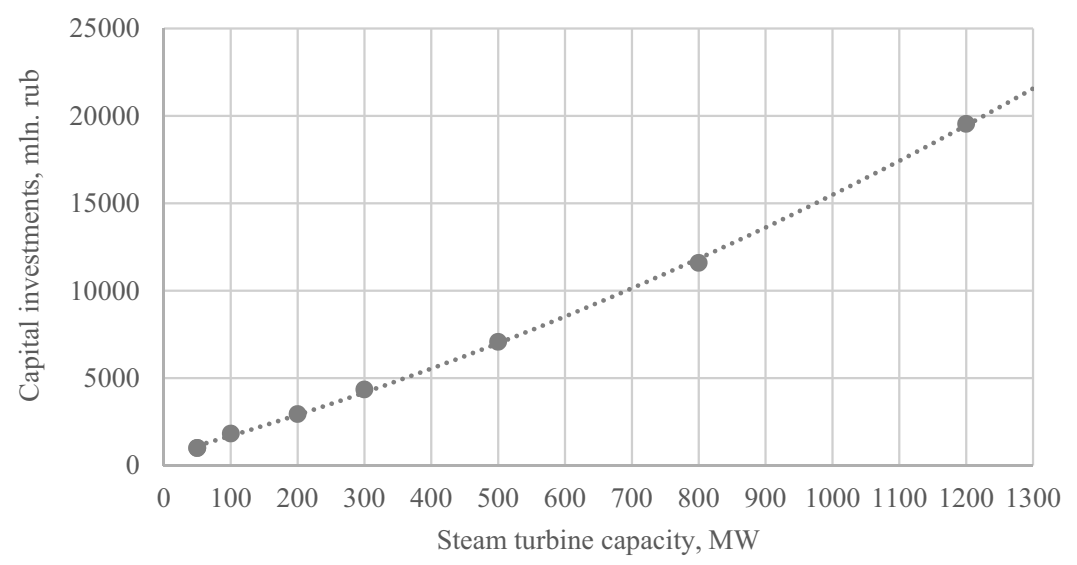

Figure 4. Generation equipment cost forecast with installed capacity growth Source: own research.

It should be noted that, that metal cost determination for generation equipment requires more detailed consideration and possibly special model construction as the cost of power unit single parts varies enormously depending on application and location.

\section{CONCLUSIONS}

Power industry is the key sector ensuring a sustainable development of national economy. National security of energy supply is determined by the level of efficiency and reliability in power industry. Priority rates of energy sector development are expected in comparison with other sectors of economy due to necessity of meeting constantly growing requirements of economy in electric power.

Evaluation of world data on construction of all kinds of generating facilities allows for the conclusion that despite the achieved capacity gain of alternative and renewable energy sources over the past decade, the increase of typical fuel and energy resources (oil, gas, coal) consumption is observed, and traditional thermal power industry based on chemical transformation of organic fuel still dominates. Active use of organic fuel to satisfy demand for electric power along with resource limitation is among the key factors of energy conversion technological development.

Global power-plant industry development is focused on amplification of initial steam parameters, such as temperature and pressure. However, steam parameter increase is limited by physical properties of modern steel, and thus, by development level of iron and steel enterprises. Increase of initial steam parameters results in efficiency improvement of a generating unit, and escalation of capital costs as well. From the perspective of economic feasibility of high-efficient electric power generation technologies, unit power improvement shall be observed.

Russian power engineering enterprises produce the main and accessory equipment for TPP, nuclear, hydraulic and gas-turbine power plants. However, they hold quite weak positions in the domestic market. This is due to structural changes of industry in the early 1990s when world producers of power equipment built their business in Russian market. Such global companies as Siemens, Alstom, General Electric, almost completely hold the market of power-generating equipment, and supply their products for power plant 
construction and alteration. Under these conditions, the Russian power-plant industry is associated with auxiliary production.

Lack of sufficient funds available for investment in modernization of manufacturing equipment and improvement of product quality, as well as breach of time-honoured relations with partners, are also among the key reasons of the current situation for Russian enterprises. Nevertheless, demand for power equipment from Russian generating companies remains sufficiently high.

At present time, modernization of equipment and assimilation of new manufacturing technologies may enhance competitiveness of the Russian power engineering enterprises and provide security of energy supply in the country. At achieving these purposes under current economic conditions, it is necessary to manage costs of new power equipment manufacturing. Cost forecast for new power equipment during research and development stage is of prime importance. This could allow for attracting investments in power engineering sector from generating companies at early stages.

During technical and economic forecasting, dependence of new equipment production efficiency on variable and fixed costs ratio is of great importance considering predominant single-unit production in power-plant industry. As it appears from the presented prime cost structure of new power equipment manufacturing, the majority of costs are expended on materials by power engineering enterprises.

On the other hand, manufacturing process improvement results in reduction of metal consumption per unit capacity, on the other hand, turbo generator mass increases and it is necessary to use pricier heatresistant steel. Statistical assessment of the impact of a power unit capacity on the used metal amount is exaggerated.

Cost forecast for mastering the manufacture of advanced generation equipment (through the example of steam turbines) by Russian enterprises proved the price competitiveness of the given type of products. Increasing the share of expenses for research and development by means of mobilization of resources from generation enterprises, the Russian power-plant industry can realize considerable technological potential and achieve dominant positions in the domestic and global markets of power generation technologies.

\section{ACKNOWLEDGEMENTS}

The paper was partially supported by the Ministry of Education and Science of the Russian Federation, research project No. 26.1795.2014/K.

\section{REFERENCES}

Białowąs, P. (2015), The models of business organization in the light of the privatization process on the example of Polish electricity sector, Journal of International Studies, Vol. 7, No 3, pp. 234-243

Bechtel Power Corporation (1981), Report No PE-1865 "Coal-fired power plant capital cost estimates", San Francisco, $182 \mathrm{p}$.

Breeze, P. (2014), Power generation technologies. Oxford: Newnes, 408 p.

Cardu, M., Atanasiu, V. (1994), Results of the international cooperation in the thermopower equipment achievement field, Energy conversion and management, Vol. 35, no. 9, pp. 815-825.

Colpier, U. C., Cornland, D. (2002), The economics of the combined cycle gas turbine - an experience curve analysis. Energy Policy, Vol. 30, no. 4, pp. 309-316.

Danilin, I. (2010), The evolution of Russian conceptual and political models of high technology cooperation with foreign nations and multinational corporations connections. The Quarterly Journal, Vol. 9, no. 2, pp. 51-65. 
Delgado, M., Porter, M. E., Stern, S. (2016), Defining clusters of related industries. Journal of Economic Geography, Vol. 16, no. 1 , pp. 1-38

Frolova, E. V. (2014). Deformations in interbudget relations in Russian Federation: Socioeconomic and political risks. Actual Problems of Economics, 158(8), 351-359.

Hill, M. R. (1998), From Soviet giants to Russian survivors. Leadership \& Organization Development Journal, Vol. 19, no. 6, pp. 325-331.

International Energy Statistics (2016), Available at: http://www.eia.gov/cfapps/ipdbproject/IEDIndex3.cfm (accessed: 2016, August, 1).

Kehlhofer, R., Hannemann, F., Rukes, B., Stirnimann, F. (2009), Combined-cycle gas \& steam turbine power plants. Tulsa: Pennwell Books, 433 p.

Leyzerovich, A. S. (2008). Steam turbines for modern fossil-fuel power plants. Lilburn: Fairmont Press, 529 p.

Lisin, E., Rogalev, A., Strielkowski, W., Komarov, I. (2015a), Sustainable modernization of the Russian Power Utilities Industry. Sustainability, Vol. 7, no. 9, pp. 11378-11400.

Lisin, E.; Strielkowski, W., Komarov, I., Garanin, I. (2015b), Improving the methodology of main power equipment choice for the gas turbine plants. Electronics, Vol. 19, no. 2, pp. 80-87.

Makridakis, S., Wheelwright S., Hyndman, R. (1998), Forecasting: methods and applications. New Jersey: John Wiley \& Sons, $656 \mathrm{p}$.

Masuyama, F. (2001), History of power plants and progress in heat resistant steels. ISIJ International, Vol. 41, no. 6, pp. 612-625.

Mikhailov, V. E., Khomenok, L. A., Kruglikov, P. A., Moiseeva, L. N. (2012), Strategic goals to be pursued by scientifictechnical progress in the Russian industry constructing power machinery and equipment for the period up to 2020-2030, Thermal Engineering, Vol. 59, no. 7, pp. 491-496.

Mityushin, V. S., Moiseeva, L. N., Petrenya, Y. K. (2008), Development of Russia’s power engineering in the long term and new challenges faced by the industry of constructing power machinery and equipment, Thermal engineering, Vol. 55, no. 1, pp. 4-8.

Rodionov, D. G., Guzikova, L. A., \& Rudskaya, I. A. (2014). Innovation potential of regions as a factor of national economy competitiveness. Actual Problems of Economics, 158(8), 215-223.

Rezinskikh, V. F. (2010), Reliability and safety of thermal power stations in Russia at the present stage: problems and future objectives, Thermal engineering, Vol. 57, no. 1, pp. 1-8.

Rubin, E. S., Chen, C., Rao, A. B. (2007), Cost and performance of fossil fuel power plants with $\mathrm{CO}_{2}$ capture and storage. Energy policy, Vol. 35, no. 9, pp. 4444-4454.

Salnikov, V. A., Galimov, D. I. (2006). The competitiveness of Russian industries: current state and outlook, Studies on Russian Economic Development, Vol. 17, no. 2, pp. 149-168.

Sargent \& Lundy, LLC. (2009). Report No SL-009808 "New coal-fired power plant performance and cost estimates", Chicago, $82 \mathrm{p}$.

Streimikiene, D., Strielkowski, W., Bilan, Y., Mikalauskas, I. (2016). Energy dependency and sustainable regional development in the Baltic States-a review. Geographica Pannonica, Vol. 20, No, 2, pp. 79-87

Urbaniec, M. (2015). Towards Sustainable Development through Eco-innovations: Drivers and Barriers in Poland. Economics and Sociology, Vol. 8, No. 4, pp. 179-190

Zhang, D. (2013), Ultra-supercritical coal power plants: materials, technologies and optimization. Cambridge: Woodhead Publishing, 273 p. 